\title{
Latent Heat of Amorphous Slags and Their Utilization as a High Temperature PCM
}

\author{
Yoshiaki KASHIWAYA, ${ }^{1)}$ Tomohiro AKIYAMA ${ }^{2)}$ and Yutaro IN-NAMI ${ }^{3)}$ \\ Formerly Graduate School of Engineering, Hokkaido University. Now at Department of Energy Science and Technology, Kyoto \\ University, Sakyo-ku, Yoshida Honmachi, Kyoto 606-8501 Japan. 2) Center for Advanced Research of Energy \\ Conversion Materials, Hokkaido University, 3$)$ Formerly Student of Graduate School of Engineering, Hokkaido
} University. Now at Sumitomo Metal Industries, Ltd.

(Received on February 16, 2010; accepted on April 30, 2010)

In a previous study, a rotary cylinder atomizing (RCLA) method for slag was developed and the slag spouting behavior from a nozzle was investigated. The theoretical approach of the previous study agreed well with the observed result.

In this study, the potential of slag particles obtained by RCLA method as a phase changing material (PCM) was investigated.

The latent heats and the temperature ranges of heat generation were measured for two kinds of amorphous slags (slag particles and water granulated-slag from blast furnace) using DTA (differential thermal analysis).

Mathematical simulation of a countercurrent heat exchanger was performed and the effect of slag latent heat on gas temperature was estimated. The temperature range of the latent heat of amorphous slag was estimated to range from 800 to $950^{\circ} \mathrm{C}$. The values of latent heat for slag particles and the water-granulated slag were $294 \mathrm{~kJ} / \mathrm{kg}$ and $235 \mathrm{~kJ} / \mathrm{kg}$, respectively.

Simulation results indicated that the latent heat of slag can decrease the temperature of waste gas which might increased the usable kind of waste gas.

KEY WORDS: slag recycle; amorphous slag; rotary cylinder atomizing; PCM.

\section{Introduction}

Finding new ways to decrease $\mathrm{CO}_{2}$ emission in order to preserve the environment is an important challenge in the Japanese steel industry. In a previous paper, ${ }^{1)}$ two methods of rotary cylinder atomization (RCLA) of blast furnace (BF) slag were developed, and the slag particles obtained from these processes were analyzed. Using a high-speed camera, the spouting behaviors of slag from nozzles were observed and compared to a theoretical explanation of slag atomization in another paper. ${ }^{2)}$ The relationship between slag particle diameter $(d)$ and nozzle diameter $(2 a)$ was derived as follows:

$$
2 a=\frac{\pi^{2} \rho L Z^{2}}{5400 \gamma} d^{3}
$$

where $\rho$ is density, $L$ is the distance from the center of rotation to the tip of the slag string, $Z$ is rotation speed and $\gamma$ is surface tension of slag.

The flow rate of slag was evaluated using HagenPoiseuille's equation, and the relationship between particle diameter and slag string diameter was obtained using Weber's equation. From a comparison of experimental results and theoretical calculations, it was concluded that a string diameter of $0.2 \mathrm{~mm}$ for a nozzle with a diameter of $1.3 \mathrm{~mm}$ was adequate in this experiment.
On the other hand, it is important to develop a way of utilization for the obtained slag particles. The slag particles have two characteristic features, one is a small sphere around $1 \mathrm{~mm}$ in diameter and the other is an amorphous phase. The later feature means that the material has a latent heat of crystallization, which is a huge enthalpy, because about 38 Mton of slag per year are produced in Japan. In the present study, we investigated the possibility of an amorphous slag as a PCM (Phase Change Material). The general recognition to PCM may be that the material itself is used for many times. However, in the case of slag, as the huge amount and high temperature of slags are exhausted, the reuse of slag for PCM is not necessary. This is a quite large advantage of slag as a PCM.

In this study, the utilization of slag particles by the RCLA method was investigated. Particularly, the amorphous phase of slag has a latent heat of crystallization. The temperature range of crystallization and the amount of latent heat of slag particles were measured and compared to those of water-granulated slag. Because there is a huge amount of readily available water-granulated slag, it would be highly desirable as a high temperature phase change material (PCM) if its latent heat can be utilized. One example of the utilization as the slag PCM was shown using mathematical simulation. The subject of simulation is a waste heat recovery from high temperature gas more than $900^{\circ} \mathrm{C}$ 
such as a LD converter gas. Using a countercurrent heat exchanger, amorphous slag is heated by the waste gas and the lower temperature gas can be used for other process. This simulation is supposing a cascade utilization of waste gas, because, some time, it is difficult to utilize the gas in high temperature. The utilization of latent heat of slag crystallization can decrease the temperature of waste gas, or in other words, even a lower grade waste heat can be used.

\section{Experimental}

The experimental apparatus and procedure for making the slag particles are the same as that described in a previous paper. ${ }^{1)}$

The slag sample used in this study consists of BF slag, wherein its chemical composition is summarized in Table 1. The slag particles used in this study were fabricated using a multi-nozzle rotary cylinder at a rotational speed of $3000 \mathrm{rpm}$ and with a $1.3-\mathrm{mm}$ diameter nozzle. The obtained slag particles were served for differential thermal analysis (DTA) and differential scanning calorimetry (DSC), in the both measurement, samples $(20 \mathrm{mg}, 0.5-$ $1.0 \mathrm{~mm} \phi)$ were set in a Pt pan $(5 \mathrm{~mm} \phi, 2.5 \mathrm{~mm}$ in height). The temperature range of latent heat formation and the latent heat were determined. In addition, XRD (X-ray diffraction) analysis and optical microscope observation before and after experiment were performed.

\section{Results and Discussion}

\subsection{Measurement of the Temperature Range of Latent Heat Generation}

In this experiment, amorphous phase slag particles obtained from the multi-nozzle rotary cylinder were used. If the latent heat of crystallization could be utilized, energy could be saved and $\mathrm{CO}_{2}$ reduction is possible; however, there is no data in the literature concerning the latent heat of amorphous slag.

Figure 1 depicts the TTT (time-temperature-transformation) diagram of BF slag measured by Kashiwaya et al. ${ }^{3)}$ It

Table 1. Chemical composition of BF slag.

\begin{tabular}{|c|c|c|c|c|c|c|c|c|}
\hline & $\mathrm{CaO}$ & $\mathrm{SiO}_{2}$ & $\mathrm{Al}_{2} \mathrm{O}_{3}$ & $\mathrm{MgO}$ & $\mathrm{FeO}$ & $\mathrm{MnO}$ & $\mathrm{P}_{2} \mathrm{O}_{5}$ & $\mathrm{C} / \mathrm{S} \mathrm{(-)}$ \\
\hline BF slag & 42.99 & 33.52 & 13.77 & 6.28 & 0.37 & 0.27 & $<0.02$ & 1.28 \\
\hline
\end{tabular}

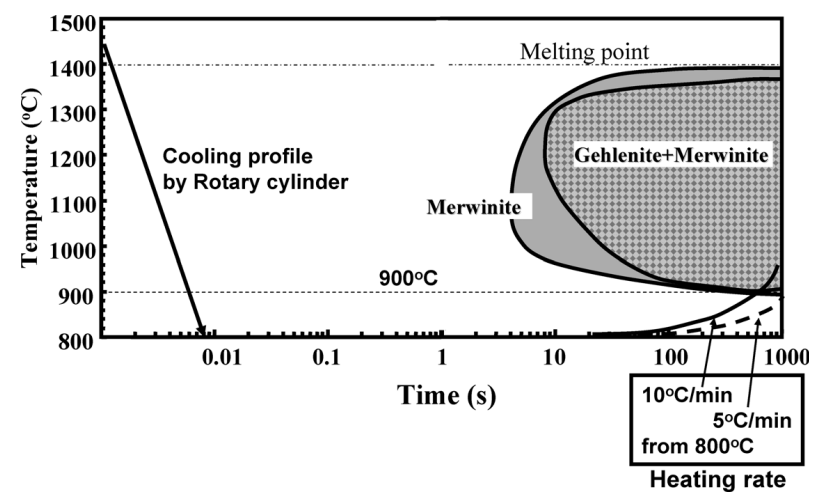

Fig. 1. TTT diagram of blast furnace slag obtained by Kashiwaya et al. $^{3 \text { ) }}$ was observed that two kind of crystals, Gehlenite $\left(2 \mathrm{CaO} \cdot \mathrm{Al}_{2} \mathrm{O}_{3} \cdot \mathrm{SiO}_{2}\right)$ and Merwinite $\left(3 \mathrm{CaO} \cdot \mathrm{MgO} \cdot 2 \mathrm{SiO}_{2}\right)$, precipitate in BF slag. The nose of the TTT diagram depicted in Fig. 1 occurs at $1100^{\circ} \mathrm{C}$ and $4 \mathrm{~s}$, which corresponds to the area of Merwinite, whereas the area of Gehlenite is covered by the area of Merwinite.

In Fig. 1, the glassy area is expressed until $0.001 \mathrm{~s}$. When the multi-nozzle rotary cylinder was operated at $3000 \mathrm{rpm}$ with a $1.3-\mathrm{mm}$ diameter nozzle, the slag spouted from the nozzle consisted of a string shape that quickly separated in particles. During this fabrication process, if a slag particle hit the wall of the container, its shape was not spherical. In a previous paper, ${ }^{1)}$ it was observed that the temperature of slag particles decreased from 1450 to $800^{\circ} \mathrm{C}$ within $0.0085 \mathrm{~s}$, which is not hot enough to deform the slag sphere.

The estimated cooling rate is also plotted on the Fig. 1, wherein it can be observed that the slag has enough time to stay amorphous phase.

The temperature profiles depicted in Fig. 1 resulted when the amorphous slag was heated to temperatures greater than $800^{\circ} \mathrm{C}$ at heating rates of $10^{\circ} \mathrm{C} / \mathrm{min}$ or $5^{\circ} \mathrm{C} / \mathrm{min}$. These heating curves intersected the crystallization area at approximately $900^{\circ} \mathrm{C}$ in Fig. 1 . If the temperature had been initially increased from room temperature instead of from $800^{\circ} \mathrm{C}$, which could not have been plotted in Fig. 1, the aforementioned heating curves might have intersected the crystallization area at approximately $800^{\circ} \mathrm{C}$ due to a gradual decrease of the low temperature side of the crystallization area over time.

The temperature range of amorphous slag latent heat generation was measured using DTA at a heating ramp of $5^{\circ} \mathrm{C} / \mathrm{min}$ up to $1300^{\circ} \mathrm{C}$. The obtained result of this measurement is depicted in Fig. 2. It is difficult to determine the baseline of DTA because it changes with heating rate and is affected by heat generation in the sample. It is important to compare collected DTA data to the baseline of an empty crucible. Nonetheless, the baseline was sometimes moved by unknown causes. An endothermic dehydration reaction at less than $100^{\circ} \mathrm{C}$ can be observed in Fig. 2, on the other hand, the baseline around $1200^{\circ} \mathrm{C}$ quickly increased because the furnace control was changed for a maximum temperature of $1300^{\circ} \mathrm{C}$. Except for these temperature ranges, a heat evolution was observed from 550 to $1000^{\circ} \mathrm{C}$. A dehydration reaction observed at a temperature less than $100^{\circ} \mathrm{C}$ is most likely due to adsorbed water on the surface of the

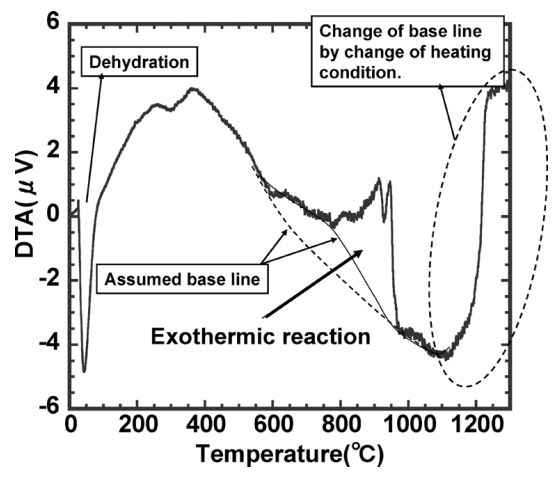

Fig. 2. DTA curve of blast furnace slag particles obtained from a multi-nozzle rotary cylinder. 
slag while it was kept in an ambient atmosphere. As mentioned in a previous paper, ${ }^{1)}$ the slag particles used in this study typically have many small holes on the surface. In addition, many traces of gas bubbles inside the particle near surface which precipitated during solidification were found. It was considered that the holes on the surface was connected to the gas bubbles near surface. These holes also provide an additional surface area that increases moisture adsorption.

Figure 2 depicts the possible two baseline changes in the temperature range from 550 to $1000^{\circ} \mathrm{C}$. To make clear the intrinsic baseline, the samples were quenched from 600 and $950^{\circ} \mathrm{C}$, as depicted in Fig. 3 (the slag particles used here consisted of mixtures of glassy but relatively large and sticking particles). Figure 3(a) depicts the appearances of slag particles before and after heat treatment at $600^{\circ} \mathrm{C}$. There was no change in slag particle appearance at $600^{\circ} \mathrm{C}$, whereas the slag particles were observed to have been crystallized by the heat treatment at $950^{\circ} \mathrm{C}$ (Fig. 3(b)). XRD patterns after heat treatments at $600^{\circ} \mathrm{C}$ and $950^{\circ} \mathrm{C}$ are depicted in Figs. 4(a) and 4(b), respectively, wherein it can be seen that the originally amorphous slag particles annealed at $600^{\circ} \mathrm{C}$ were amorphous (XRD pattern was the same as before heating) and those at $900^{\circ} \mathrm{C}$ were crystalline.

The crystalline phases in the slag particle annealed at $950^{\circ} \mathrm{C}$ consisted of Merwinite and Gehlenite, as indicated by the TTT diagram (Fig. 1). From this result, the baseline of the DTA was determined and is depicted by the solid line
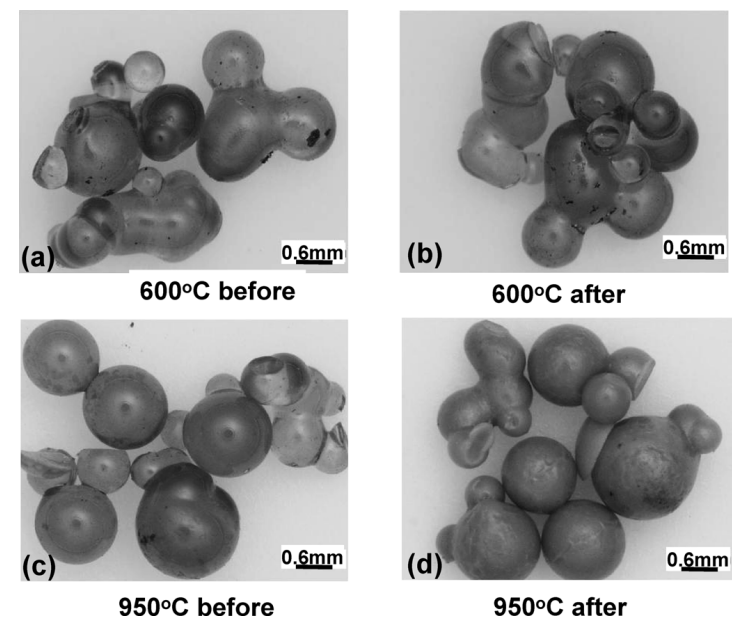

Fig. 3. Comparison of slag particles before and after annealing at different temperatures $\left(600^{\circ} \mathrm{C}\right.$ and $\left.950^{\circ} \mathrm{C}\right)$.



Fig. 4. Comparison of XRD patterns of amorphous and crystallized slag particles annealed at $600^{\circ} \mathrm{C}$ and $950^{\circ} \mathrm{C}$, respectively. in Fig. 2.

\subsection{Measurement of the Latent Heat of Amorphous Water-granulated Slag and Slag Particles}

The latent heat of amorphous slag was measured using DTA and DSC. Although it is difficult to determine the baseline of the peak of heat generation in the case of DTA, a reliable baseline was identified via quenching at several temperatures, as previously mentioned.

In this study, the latent heat of water-granulated slag was measured such that it could be a point of comparison for the slag particles. Since there are substantial amounts of water-granulated slag available, it would be potentially valuable to use these materials as high temperature PCMs if their latent heats could be utilized. Unfortunately, it was observed that water-granulated slag degraded with time. Within one year, the amorphous phase was preserved; however, the slag gradually crystallized over periods of more than one year (Fig. 5).

In the present study, the latent heats of three kinds of slag, new water-granulated slag (within 1 month of production), old water-granulated slag (more than 1 year old), and slag particles, were measured using DTA and DSC.

DTA measurement was conducted using a heating ramp of $5^{\circ} \mathrm{C} / \mathrm{min}$ until $1100^{\circ} \mathrm{C}$ under an Ar atmosphere, and the results are summarized in Fig. 6. The old water-granulated slag exhibited no exothermic reaction peak in the temperature range of 800 to $950^{\circ} \mathrm{C}$. In contrast, the new water-granulated slag and the slag particles obtained in the present study exhibited exothermic reactions of crystallization in this same temperature range. The maximum peak for the new water-granulated slag was observed at $930^{\circ} \mathrm{C}$, whereas the slag particles exhibited two exothermic reaction peaks,

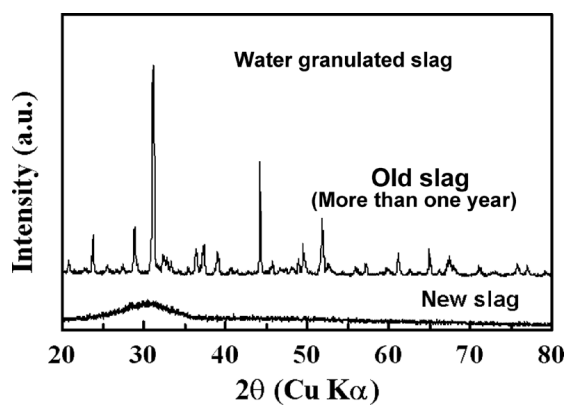

Fig. 5. Comparison of XRD patterns of new water-granulated slag to water-granulated slag more than one year old.



Fig. 6. Comparison of slag particle, new water-granulated slag, and old water-granulated slag DTA curves. 
most likely corresponding to the crystallizations of Merwinite and Gehlenite phases. The area of the exothermic reaction peak corresponds to the enthalpy change of crystallization (latent heat), $\Delta H_{\text {cry }}$.

The area of the heat generation, $A_{\mathrm{S}}$, can be related to the latent heat of crystallization $\left(\Delta H_{\text {cry }}\right)$ using $R_{\mathrm{S}}$, which is an instrumental constant and represents the thermal resistance between the sample and the sample-temperature measuring point. $^{4)}$

$$
A_{\mathrm{S}}=R_{\mathrm{S}} \Delta H_{\text {cry }}
$$

Because the value of $R_{\mathrm{S}}$ for DTA is an instrumental constant, it was estimated in advance by comparing the DTA results to the DSC results; however, the usage of DSC was limited in the authors' laboratory, and therefore, DTA was primarily used for thermal analysis.

The obtained latent heats of slag particles and new watergranulated slag were $294 \mathrm{~kJ} / \mathrm{kg}$ and $235 \mathrm{~kJ} / \mathrm{kg}$, respectively, as shown in Fig. 6. This difference in latent heat results from the respective slag treatments, wherein the former slag was made using a dry quenching method (slag particle) and the latter by a water quenching method. The lower latent heat of the water-granulated slag $(235 \mathrm{~kJ} / \mathrm{kg})$ in comparison to the slag particles $(294 \mathrm{~kJ} / \mathrm{kg})$ is most likely due to some degradation caused by a reaction with water.

Figure 7 compares XRD patterns of new water-granulated slag and slag particles after DTA measurement conducted with a heating ramp of $5^{\circ} \mathrm{C} / \mathrm{min}$ to a maximum temperature of $950^{\circ} \mathrm{C}$ under an $\mathrm{Ar}$ atmosphere. From this figure, it can be observed that both slags were completely crystallized and consisted of Gehlenite and Merwinite crystal phases.

Table 2 depicts the results of slag latent heat measurement and the corresponding estimated decrease in $\mathrm{CO}_{2}$ per year. Approximately 25 Mton of BF slag is produced per

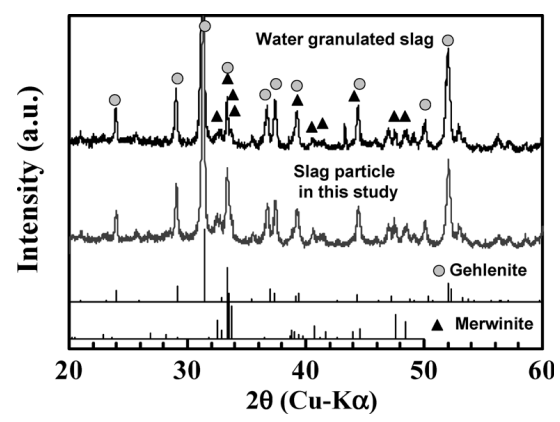

Fig. 7. Comparison of new water-granulated slag and slag particle XRD patterns after DTA measurement (maximum temperature: $950^{\circ} \mathrm{C}$ ).

Table 2. Latent heats of slags and the corresponding estimated decrease in $\mathrm{CO}_{2}$ emission.

\begin{tabular}{|c|c|c|c|c|c|}
\hline \multirow[t]{2}{*}{ BF-slag } & \multirow{2}{*}{$\begin{array}{l}\text { Production } \\
\text { (ton/year) }\end{array}$} & \multirow{2}{*}{$\begin{array}{c}\text { Latent heat } \\
(\mathrm{kJ} / \mathrm{kg}) \\
(\mathrm{MJ} / \mathrm{ton})\end{array}$} & \multirow{2}{*}{$\begin{array}{c}\text { Total } \\
\text { energy } \\
\text { (MJ/year) }\end{array}$} & $\begin{array}{c}\mathrm{CO}_{2}^{*} \\
(\mathrm{~kg} / \text { year })\end{array}$ & \multirow{2}{*}{$\begin{array}{l}\text { Percent to } \\
1990 \text { 's CO } \\
\text { emission ** }\end{array}$} \\
\hline & & & & (ton/year) & \\
\hline \multirow{2}{*}{$\begin{array}{l}\text { Water-granulated } \\
\text { slag }\end{array}$} & \multirow{4}{*}{$25 \times 10^{6}$} & \multirow{2}{*}{235} & \multirow{2}{*}{$5.88 \times 10^{9}$} & $3.94 \times 10^{8}$ & \multirow{2}{*}{$0.02 \%$} \\
\hline & & & & $3.94 \times 10^{5}$ & \\
\hline \multirow{2}{*}{$\begin{array}{c}\text { Dry quenched } \\
\text { slag } \\
\text { (Slag particle) }\end{array}$} & & \multirow[b]{2}{*}{294} & \multirow[b]{2}{*}{$7.35 \times 10^{9}$} & $4.92 \times 10^{8}$ & \multirow[b]{2}{*}{$0.025 \%$} \\
\hline & & & & $4.92 \times 10^{5}$ & \\
\hline
\end{tabular}

year, and the latent heats of water-granulated slag and slag particles were identified to be $235 \mathrm{~kJ} / \mathrm{kg}$ and $294 \mathrm{~kJ} / \mathrm{kg}$, respectively. The total energy of the latent heat is $5.88 \times$ $10^{9} \mathrm{MJ} /$ year for water-granulated slag and $7.35 \times 10^{9}$ $\mathrm{MJ} /$ year for slag particles. When a conversion factor of $0.067 \mathrm{~kg}-\mathrm{CO}_{2} / \mathrm{MJ}$ is assumed for the estimation of $\mathrm{CO}_{2}$ emission from heat, the amount of $\mathrm{CO}_{2}$ emitted was 0.394 Mton for water-granulated slag and 0.492 Mton for slag particles, which corresponds to $0.02 \%$ and $0.025 \%$ decreases in $\mathrm{CO}_{2}$ emission, respectively, by the steel industry in 1990. Although this is a small percentage relative to the entire $\mathrm{CO}_{2}$ emission of the steel industry, the absolute value of $\mathrm{CO}_{2}$ emission reduction is substantial.

The latent heats and melting points of PCMs are summarized in Table 3 and Fig. 8. ${ }^{5-11)}$ In Fig. 8, the latent heat of BF slag obtained in this study is also plotted against its melting point (about $1450^{\circ} \mathrm{C}$ ). The order of the amorphous slag's latent heat is not very low, and BF slag melts at a very high temperature as a PCM. Therein, amorphous slag could act as a high temperature PCM, such that high temperature waste gas, such as converter exhaust, which is typically at a temperature of $1500^{\circ} \mathrm{C}$, could utilize it. One example for the utilization of slag as a PCM is considered in the next section.

\subsection{Process Image and Simulation of the Utilization of the Latent Heat of Slag as a PCM}

\subsubsection{Process Image}

In the present study, a high temperature waste converter exhaust gas consisting of $100 \% \mathrm{CO}$ and a temperature of at least $800^{\circ} \mathrm{C}$ (maximum $1500^{\circ} \mathrm{C}$ ) was assumed. The process image is shown in Fig. 9. The process consists of two parts. The first part consists of a countercurrent heat exchanger between high temperature $\mathrm{CO}$ gas and low temperature amorphous slag (Fig. 9(a)), which is the primary part of the simulation in this study. Since the slag is exhausted from the bottom of the exchanger, it is necessary to develop a heat exchanger to utilize the residual heat of the slag. The waste gas from the converter is batch type, and therefore, it works as a time adjusting system. The image depicted in Fig. 9(a) can also work as a time-adjusting process, and furthermore, it is important to use the residual heat of the slag, as shown in Fig. 9(b). This process is a cascade-like utilization of slag heat depending on the temperature range. ${ }^{12,13)}$

\subsubsection{Simulation Model of the Countercurrent Heat Ex- changer}

The simulation model was developed on the basis of a blast furnace simulation. ${ }^{14)}$ The differential equation is expressed by mass balance (Eq. (3)) and heat balance (Eq. (4)):

$$
\begin{array}{r}
d\left(C_{\mathrm{S}} V_{\mathrm{S}}\right) / d z=0 \ldots \ldots \ldots \ldots \ldots \\
d\left(V_{\mathrm{S}} \overline{C_{\mathrm{P}}} C_{\mathrm{S}} T_{\mathrm{S}}\right) d z=H_{\mathrm{P}} A_{\mathrm{P}}\left(T_{\mathrm{S}}-T_{\mathrm{G}}\right)+Q
\end{array}
$$

subscript $\mathrm{S}, \mathrm{G}$ : solid and gas

$C_{\mathrm{S}}: \quad$ Concentration of solid $\left(\mathrm{kmol} / \mathrm{m}^{3}\right.$-bed)

$A_{\mathrm{P}}$ : Specific surface area of solid $\left(\mathrm{m}^{2} / \mathrm{m}^{3}\right.$-bed $)$

$\overline{C_{\mathrm{P}}}$ : Specific heat $\left(\mathrm{kJ} / \mathrm{kmol} \cdot{ }^{\circ} \mathrm{C}\right)$

$H_{\mathrm{P}}$ : Heat transfer coefficient between solid and gas $\left(\mathrm{kJ} / \mathrm{m}^{2} \cdot \min \cdot{ }^{\circ} \mathrm{C}\right)$

$Q: \quad$ Rate of heat evolution $\left(\mathrm{kJ} / \mathrm{min} \cdot \mathrm{m}^{3}\right.$-bed $)$ 
ISIJ International, Vol. 50 (2010), No. 9

Table 3. Latent heats and melting points of possible PCM candidates. ${ }^{5-11)}$

\begin{tabular}{|c|c|c|c|c|}
\hline No. & Material & m.p. $\left[{ }^{\circ} \mathrm{C}\right]$ & $\mathrm{Q}_{\mathrm{L}}[\mathrm{kJ} / \mathrm{kg}]$ & Ref. \\
\hline \multirow{2}{*}{1} & \multirow{2}{*}{ Erythritol } & 117 & 344 & 5) \\
\hline & & 118 & 314 & 7) \\
\hline 2 & $\mathrm{KNO}_{3}-\mathrm{LiNO}_{3}(67 \mathrm{wt} \%-33 \mathrm{wt} \%)$ & 133 & 170 & 6) \\
\hline 3 & $\mathrm{KNO}_{3}-\mathrm{NaNO}_{2}-\mathrm{NaNO}_{3}(53 \mathrm{wt} \%-40 \mathrm{wt} \%-7 \mathrm{wt} \%)$ & 142 & 80 & 6) \\
\hline 4 & Mannitol & 165 & 341 & 5) \\
\hline 5 & $\mathrm{LiNO}_{3}-\mathrm{NaNO}_{3}(49 \mathrm{wt} \%-51 \mathrm{wt} \%)$ & 194 & 265 & 6) \\
\hline 6 & $\mathrm{NaOH}-\mathrm{KOH} \quad(50 \mathrm{~mol} \%-50 \mathrm{~mol} \%)$ & 171 & 213 & 7) \\
\hline 7 & Penterythritol & 185 & 303 & 8) \\
\hline \multirow{2}{*}{8} & \multirow{2}{*}{ LiOH-NaOH (30mol\%-70mol\%) } & 185 (Transformation) & 58 & 7) \\
\hline & & 215 (Fusion) & 290 & 7) \\
\hline 9 & \multirow{2}{*}{$\mathrm{NaNO}_{3}-\mathrm{KNO}_{3}(50 \mathrm{~mol} \% / 50 \mathrm{~mol} \%)$} & 220 & 100.7 & 9) \\
\hline 10 & & 222 & 100 & 6) \\
\hline 11 & $\mathrm{NaOH} \cdot-\mathrm{NaNO}_{2}(20 \mathrm{~mol} \%-80 \mathrm{~mol} \%)$ & 232 & 252 & 7) \\
\hline 12 & $\mathrm{ZnCl}_{2}-\mathrm{KCl}(31.9 \mathrm{~mol}-68.1 \mathrm{~mol} \%)$ & 235 & 198 & 9) \\
\hline 13 & $\mathrm{NaOH} \cdot-\mathrm{NaNO}_{2}(73 \mathrm{~mol} \%-27 \mathrm{~mol} \%)$ & 237 & 294 & 7) \\
\hline 14 & $\mathrm{NaOH}-\mathrm{NaNO}_{3}(28 \mathrm{~mol} \%-72 \mathrm{~mol} \%)$ & 247 & 237 & 7) \\
\hline \multirow{2}{*}{15} & \multirow{2}{*}{$\mathrm{LiNO}_{3}$} & 254 & 360 & 6) \\
\hline & & 253 & 363 & 7) \\
\hline 16 & $\mathrm{NaOH}-\mathrm{NaNO}_{3}(81.5 \mathrm{~mol} \%-18.5 \mathrm{~mol} \%)$ & 257 & 292 & 7) \\
\hline 17 & $\mathrm{NaOH} \cdot \mathrm{NaNO}_{2}$ & 265 & 313 & 7) \\
\hline 18 & $\mathrm{NaOH}-\mathrm{NaNO}_{3}(59 \mathrm{~mol} \%-41 \mathrm{~mol} \%)$ & 266 & 278 & 7) \\
\hline 19 & $\mathrm{NaOH} \cdot \mathrm{NaNO}_{3}$ & 271 & 263 & 7) \\
\hline \multirow{2}{*}{20} & \multirow{2}{*}{$\mathrm{NaNO}_{2}$} & 270 & 180 & 6) \\
\hline & & 282 & 216 & 7) \\
\hline 21 & $\mathrm{ZnCl}_{2}$ & 280 & 75 & 9) \\
\hline \multirow{5}{*}{22} & \multirow{5}{*}{$\mathrm{NaNO}_{3}$} & 306 & 175 & 6) \\
\hline & & 307 & 182 & 7) \\
\hline & & 307 & 199 & 8) \\
\hline & & 308 & 199 & 10) \\
\hline & & 310 & 172 & 9) \\
\hline \multirow{3}{*}{23} & \multirow{3}{*}{$\mathrm{NaOH}$} & 293 (Transformation) & 159 & 7) \\
\hline & & 318 (Fusion) & 159 & 7) \\
\hline & & 318 (Fusion) & 165 & 9) \\
\hline \multirow{3}{*}{24} & \multirow{3}{*}{$\mathrm{KNO}_{3}$} & 330 & 266 & 9) \\
\hline & & 333 & 266 & 10) \\
\hline & & 380 & 266 & 8) \\
\hline \multirow{3}{*}{37} & \multirow{3}{*}{$\mathrm{KOH}$} & 360 & & 7) \\
\hline & & 380 & 149.7 & 9) \\
\hline & & 380 & 149.7 & 10) \\
\hline 25 & $\begin{array}{l}\mathrm{NaCl}-\mathrm{KCl}-\mathrm{MgCl}_{2} \\
(33.0-21.6-45.4 \mathrm{~mol} \%)\end{array}$ & 385 & 234 & 7) \\
\hline
\end{tabular}

\begin{tabular}{|c|c|c|c|c|}
\hline No. & Material & Temp., m.p. $\left[{ }^{\circ} \mathrm{C}\right]$ & $\mathrm{Q}_{\mathrm{L}}[\mathrm{kJ} / \mathrm{kg}]$ & Ref. \\
\hline 26 & $\mathrm{Li}_{2} \mathrm{CO}_{3}-\mathrm{Na}_{2} \mathrm{CO}_{3}-\mathrm{K}_{2} \mathrm{NO}_{3}(43.5-31.5-25.0 \mathrm{~mol} \%)$ & 397 & 274 & 7) \\
\hline 27 & $2 \mathrm{KCl} \cdot \mathrm{MgCl}_{2}$ & 435 & 184 & 7) \\
\hline 28 & $\mathrm{NaCl}-\mathrm{MgCl}_{2}(60.1-39.9 \mathrm{~mol} \%)$ & 450 & 293 & 7) \\
\hline 29 & LiF-NaF-KF (46.5-11.5-42.0mol\%) & 454 & 400 & 7) \\
\hline 30 & $\mathrm{LiOH}$ & 462 & 875 & 7) \\
\hline 31 & $\mathrm{KCl} \cdot-\mathrm{MgCl}_{2}(42.0-58.0 \mathrm{~mol} \%)$ & 470 & 392 & 7) \\
\hline 32 & $\mathrm{Li}_{2} \mathrm{CO}_{3}-\mathrm{K}_{2} \mathrm{NO}_{3}(62.0-38.0 \mathrm{~mol} \%)$ & 488 & 370 & 7) \\
\hline 33 & $\mathrm{Li}_{2} \mathrm{CO}_{3}-\mathrm{NaCO}_{3}(53.3-46.7 \mathrm{~mol} \%)$ & 496 & 372 & 7) \\
\hline 34 & Al-Si(88-12wt\%) & 576 & 560 & 10) \\
\hline 35 & $\mathrm{Al}-\mathrm{Si}(80-20 \mathrm{wt} \%)$ & 585 & 460 & 10) \\
\hline \multirow{2}{*}{36} & \multirow{2}{*}{$\mathrm{MgCl}_{2}$} & 714 & 453 & 7) \\
\hline & & 800 & 492 & 8) \\
\hline 37 & $\mathrm{LiF}_{-\mathrm{CaF}_{2}(79-21 \mathrm{~mol} \%)}$ & 765 & 757 & 7) \\
\hline 38 & $\mathrm{KCl}$ & 770 & 355 & 7) \\
\hline \multirow{3}{*}{39} & \multirow{3}{*}{$\mathrm{NaCl}$} & 800 & 483 & 7) \\
\hline & & 802 & 492 & 8) \\
\hline & & 802 & 466.7 & 10) \\
\hline 40 & $\mathrm{LiF}$ & 848 & 1037 & 7) \\
\hline 41 & $\mathrm{Na}_{2} \mathrm{CO}_{3}$ & 854 & 275.7 & 10) \\
\hline \multirow{2}{*}{42} & \multirow{2}{*}{$\mathrm{KF}$} & 857 & 452 & 8) \\
\hline & & 858 & 507 & 7) \\
\hline 43 & $\mathrm{~K}_{2} \mathrm{CO}_{3}$ & 897 & 235.8 & 10) \\
\hline 44 & $\mathrm{Ag}$ & 962 & 104.6 & 11) \\
\hline \multirow{2}{*}{45} & \multirow{2}{*}{$\mathrm{NaF}$} & 996 & 796 & 11) \\
\hline & & 995 & 801 & 7) \\
\hline 46 & $\mathrm{MgF}_{2}-\mathrm{NaF}(64-36 \mathrm{~mol} \%)$ & 1000 & 794 & 11) \\
\hline 47 & $\mathrm{KF}-\mathrm{MgF}_{2}(31-69 \mathrm{~mol} \%)$ & 1008 & 710 & 11) \\
\hline 47 & $\mathrm{Au}$ & 1064 & 64.5 & 11) \\
\hline 49 & $\mathrm{Sm}$ & 1072 & 57.5 & 11) \\
\hline 50 & $\mathrm{Cu}$ & 1084 & 209.4 & 11) \\
\hline 51 & $\mathrm{Na}_{2} \mathrm{O}$ & 1132 & 770 & 11) \\
\hline 52 & $\mathrm{Mn}$ & 1244 & 265.5 & 11) \\
\hline \multirow{2}{*}{53} & \multirow{2}{*}{$\mathrm{MgF}_{2}$} & 1263 & 942 & 11) \\
\hline & & 1263 & 883 & 11) \\
\hline 54 & $\mathrm{Be}$ & 1287 & 1754.4 & 11) \\
\hline 55 & $\mathrm{Gd}$ & 1312 & 64 & 11) \\
\hline 56 & $\mathrm{CaF}_{2}$ & 1411 & 393 & 7) \\
\hline 57 & $\mathrm{Si}$ & 1412 & 1414.3 & 11) \\
\hline 58 & Co & 1494 & 291.5 & 11) \\
\hline
\end{tabular}

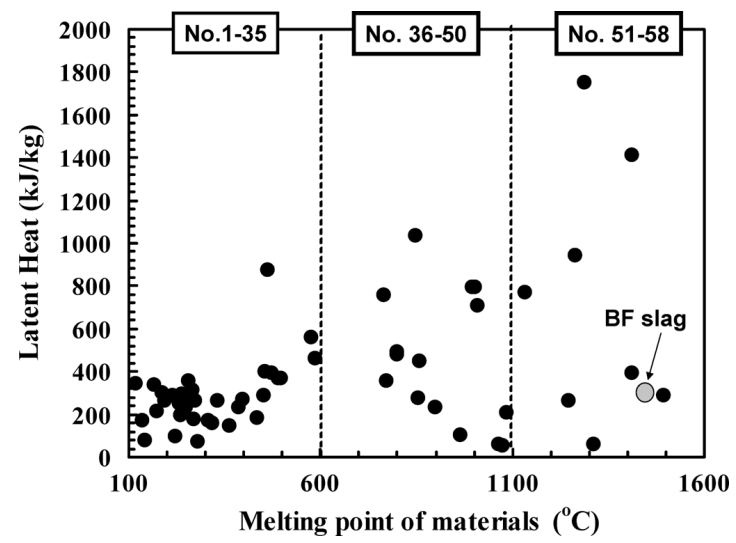

Fig. 8. Relationship between latent heat and melting point of a PCM listed in Table 3.

$T: \quad$ Temperature $\left({ }^{\circ} \mathrm{C}\right)$

$V:$ Descending velocity $(\mathrm{m} / \mathrm{min})$

$Z$ : Distance from top $(\mathrm{m})$

The temperatures of the solid and gas at step- $n T_{\mathrm{S}}^{n+1}$, $T_{\mathrm{G}}^{n+1}$ can be derived from $T_{\mathrm{S}}^{n}, T_{\mathrm{G}}^{n}$.

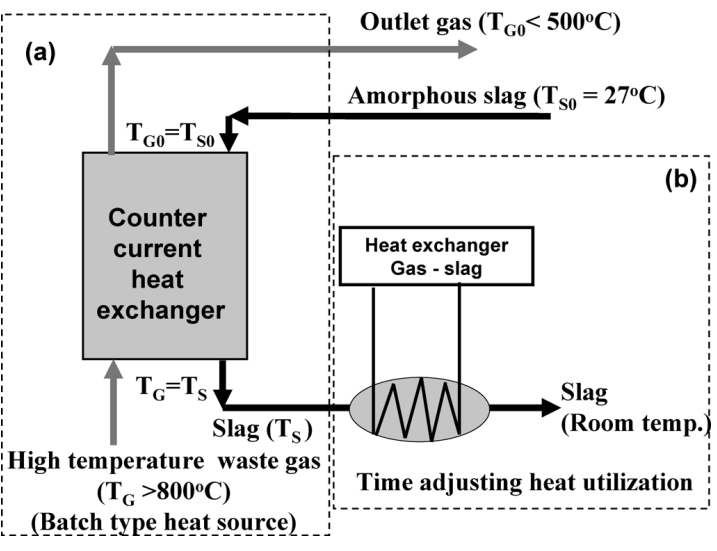

Fig. 9. Process image of the utilization of slag as a PCM.

$$
\begin{aligned}
T_{\mathrm{S}}^{n+1}= & T_{\mathrm{S}}^{n}-\frac{Q \Delta Z}{W_{\mathrm{S}}(1-\beta)} \\
& +\frac{1}{(1-\beta)}\left\{\left(T_{\mathrm{G}}^{n}-T_{\mathrm{S}}^{n}\right)+\frac{Q}{H_{\mathrm{P}} A_{\mathrm{P}}(1-\beta)}\right\} \\
& \times\left[1-\exp \left\{-\frac{H_{\mathrm{P}} A_{\mathrm{P}}(1-\beta) \Delta Z}{W_{\mathrm{G}}}\right\}\right] \ldots \ldots \ldots . . .
\end{aligned}
$$




$$
\begin{aligned}
T_{\mathrm{G}}^{n+1}= & T_{\mathrm{G}}^{n}-\frac{Q \Delta Z}{W_{\mathrm{S}}(1-\beta)} \\
& +\frac{\beta}{(1-\beta)}\left\{\left(T_{\mathrm{G}}^{n}-T_{\mathrm{S}}^{n}\right)+\frac{Q}{H_{\mathrm{P}} A_{\mathrm{P}}(1-\beta)}\right\} \\
& \times\left[1-\exp \left\{-\frac{H_{\mathrm{P}} A_{\mathrm{P}}(1-\beta) \Delta Z}{W_{\mathrm{G}}}\right\}\right] \ldots \ldots \ldots \ldots . .
\end{aligned}
$$

where $W_{\mathrm{G}}$ and $W_{\mathrm{S}}$ are the heat fluxes of a gas and solid $\left(W=V \cdot \overline{C_{\mathrm{P}}} \cdot C_{i}, i=\mathrm{S}\right.$ or $\left.\mathrm{G}\right)$, respectively, and $\beta=W_{\mathrm{S}} / W_{\mathrm{G}}$.

Calculations were performed assuming that the latent heat of slag was $0 \%, 50 \%$, and $100 \%$ of the latent heat, $Q_{\text {cry }},\left(Q=0, Q=Q_{\text {cry }} / 2\right.$, and $Q=Q_{\text {cry }}$, and $Q_{\text {cry }}$ is assumed to be $230 \mathrm{~kJ} / \mathrm{kg}$ ). The temperature range of latent heat generation was fixed from 800 to $950^{\circ} \mathrm{C}$, and the rate of heat generation was assumed to be $96.6 \mathrm{~kJ} / \mathrm{min}$ (estimated from the result of DTA). The heat generation at each step was calculated until the maximum heat reached $230 \mathrm{~kJ} / \mathrm{kg}$. In this simulation, the $\mathrm{CO}$ flow rate was $0.78 \mathrm{Nm}^{3} / \mathrm{min}$, the solid descending speed was $0.6 \mathrm{~m} / \mathrm{min}$, and the heat exchanger was cylindrical with a 1-m diameter. The height of the heat exchanger was an uncertain value that was determined from the term of $H_{\mathrm{P}} A_{\mathrm{P}}$ in Eqs. (5) and (6). Specifically, this value was used with some factor $(0.01-0.1)$ in order to fit the empirical value. ${ }^{14)}$ In the present study, $H_{\mathrm{P}} A_{\mathrm{P}}$ was assumed to be $600(\mathrm{~J} / \mathrm{m})$; however, a more accurate value should be obtained empirically.

The results of the simulation are shown in Fig. 10. The temperatures of the top were assumed to $695 \mathrm{~K}\left(422^{\circ} \mathrm{C}\right)$ and $300 \mathrm{~K}\left(27^{\circ} \mathrm{C}\right)$ for the initial temperatures of the gas and solid, respectively. Nine meters from the top, the temperature profiles of the solid and gas $\left(T_{\mathrm{S}}\right.$ and $\left.T_{\mathrm{G}}\right)$ were the same because no heat generation occurred. When heat generation occurred, the increase in temperature was largest at $Q=Q_{\text {cry }}$, while only a moderate increase in temperature occurred for $Q=Q_{\text {cry }} / 2$. When the latent heat generation occurred, the solid temperature $\left(T_{\mathrm{S}}\right)$ increased at first, but the increase of the gas temperature $\left(T_{\mathrm{G}}\right)$ delayed a little. The position becoming the same temperature between $T_{\mathrm{S}}$ and $T_{\mathrm{G}}$ is about $13 \mathrm{~m}$ from the top.

Finally, the solid and gas temperatures became the same value, which means that the slag temperature became the same temperature as the gas exhausted from the bottom. As the solid temperature decreased with increasing latent heat, $Q$, the initial gas temperature can be lower or a lower temperature waste gas can be used. Although the distance in this simulation includes a uncertain factor as mention above, the height about $13 \mathrm{~m}$ would be the most efficient length of the heat exchanger under the present simulation conditions.

If adiabatic reservation of hot slag could be established, high temperature exhaust slag could be used as a heat transportation material (Fig. 9(b)).

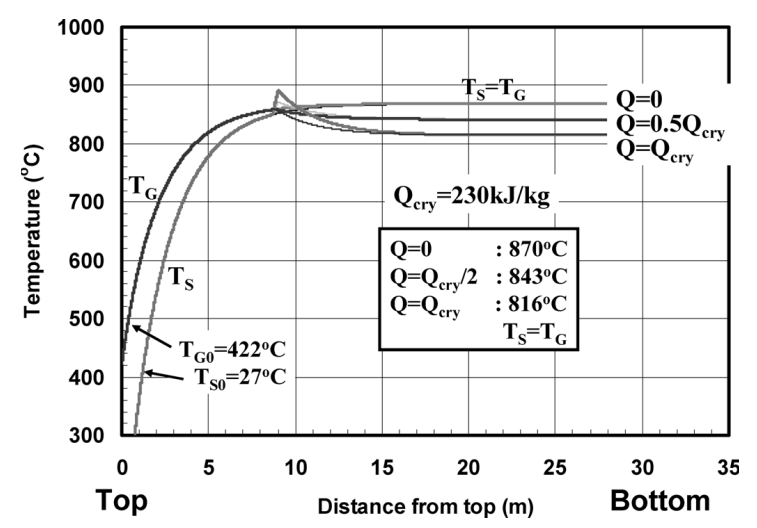

Fig. 10. Results of simulation of heat exchange between waste gas and slag particles with or without latent heat.

\section{Conclusions}

The latent heats and temperature ranges of heat generation for two kinds of amorphous slags (slag particles obtained by RCLA and water-granulated slag from a steel plant) were measured using DTA.

In addition, mathematical simulation for the countercurrent heat exchanger was performed and the effect of the latent heat of slag was estimated.

(1) The crystallization temperature of amorphous slags ranged from 800 to $950^{\circ} \mathrm{C}$.

(2) The latent heats of slag particles and the watergranulated slag were $294 \mathrm{~kJ} / \mathrm{kg}$ and $235 \mathrm{~kJ} / \mathrm{kg}$, respectively.

(3) According to simulation, the latent heat of slag can be used to lower the temperature of waste gas.

\section{REFERENCES}

1) Y. Kashiwaya, Y. In-nami and T. Akiyama: ISIJ Int., 50 (2010), 1245.

2) Y. Kashiwaya, Y. In-nami and T. Akiyama: ISIJ Int., 50 (2010), 1252.

3) Y. Kashiwaya, T. Nakauchi, P. Khanh Son, S. Akiyama and K. Ishii: ISIJ Int., 47 (2007), 44.

4) Y. Saito, K. Saito and T. Atake: Thermochim. Acta, 99 (1986), 299.

5) A. Kaizawa, N. Maruoka, A. Kawai, H. Kamano, T. Jozuka, T. Senda and T. Akiyama: Heat Mass Trans., 44 (2008), 763.

6) R. Tamme, T. Bauer, J. Buschle, D. Laing, H. M. Steinhagen and W. D. Steinmann: Int. J. Energy Res., 32 (2008), 264.

7) Japan Society of Thermophysical Properties: Sinpen Netubutsusei Handbook, Yokendou, Tokyo, (2008), 122.

8) S. D. Sharma and K. Sagara: Int. J. Green Energy, 2 (2005), 1.

9) S. Pincemin, R. Olives, X. Py and M. Christ: Solar Energy Mater. Solar. Cells, 92 (2008), 603.

10) N. Seki: Tikunetsu Kogaku, Morikita, Publ., (1995), 45.

11) N. Maruoka and T. Akiyama: Energy, 31 (2006), 1632.

12) L. Zhang and T. Akiyama: Int. J. Exergy, 6 (2009), 214.

13) T. Nomura, N. Okinaka and T. Akiyama: J. Jpn. Inst. Energy, 88 (2009), 950.

14) K. Ishii, Y. Kashiwaya, H. Yamaguchi and S. Kondo: Tetsu-toHagané, 72 (1986), 2202. 